\title{
Energy utilization of diets with different hay proportions in lactating goats
}

\author{
L Rapetti, A Tamburini, GM Crovetto, G Galassi, G Succi
}

Istituto di Zootecnia Generale, via Celoria 2, 20133 Milano, Italy

Even in intensive farming conditions, dairy goats are commonly fed rations with high forage proportions and little concentrate. For high yielding animals, this results in a lack of energy which limits milk production. Literature on energy metabolism of lactating goats fed diets with high energy and protein contents is scarce.

Six Saanen goats ( $48 \mathrm{~kg} \mathrm{BW}$ and 116 days of lactation, on average) were paired and fed ad libitum three hay/concentrate diets with 70 (diet 70), 50 (diet 50) and 30 (diet 30) percent of permanent pasture hay ( $17 \% \mathrm{CP}$ on DM) in a Latin Square design. The concentrate included $29 \%$ cereals, $17 \%$ soybean meal, $12.5 \%$ brewers grain, $10 \%$ beet pulp, maize germ expeller, maize gluten meal, sunflower meal, minerals and vitamins. Protein contents were $18.8,19.3$ and $19.8 \%$ on DM for diets 70,50 and 30 , respectively. Individual apparent digestibilities were determined on the actual ingested diets ( 8 collection days for each period), while respiratory exchanges were recorded by indirect calorimetry for the three pairs of goats ( 4 days for each pair) during digestibility.

\begin{tabular}{|c|c|c|c|c|c|c|c|}
\hline \multirow[t]{2}{*}{$\cdots \quad-\quad-$} & - & \multicolumn{2}{|c|}{$\%$ hay } & SE & \multicolumn{2}{|r|}{ Significance } & \multirow[b]{2}{*}{50 vs 30} \\
\hline & 70 & 50 & 30 & & 70 vs 50 & 70 vs 30 & \\
\hline $\mathrm{DMI}(\mathrm{g} / \mathrm{d})$ & 2091 & 2318 & 2535 & 20 & $\star \star \star$ & $\star \star \star *$ & $* \star \star \star$ \\
\hline Milk yield $(g / d)$ & 2868 & 3248 & 3508 & 46 & $\star \star \star$ & $\star * *$ & $\star * *$ \\
\hline Milk fat $(\%)$ & 2.55 & 2.66 & 2.62 & 0.04 & NS & NS & NS \\
\hline Milk protein (\%) & 2.80 & 2.81 & 2.90 & 0.07 & NS & NS & NS \\
\hline DM digestib. (\%) & 65.9 & 67.4 & 68.1 & 0.3 & ** & $* *$ & NS \\
\hline DE (\% GE) & 65.3 & 67.9 & 69.3 & 0.3 & 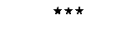 & $\star \star \star \star$ & ${ }^{\star}$ \\
\hline UE (\% GE) & 3.8 & 2.9 & 3.0 & 0.3 & NS & NS & NS \\
\hline $\mathrm{CH}_{4}-\mathrm{E}(\% \mathrm{GE})$ & 7.0 & 6.6 & 5.6 & 0.2 & NS & NS & NS \\
\hline $\mathrm{ME}(\% \mathrm{GE})$ & 54.5 & 58.4 & 60.7 & 0.4 & * & ** & * \\
\hline Heat (\% GE) & 35.8 & 33.7 & 33.4 & 0.1 & ** & $\star \star$ & NS \\
\hline Milk E (\% GE) & 17.1 & 17.8 & 18.0 & 0.2 & NS & NS & NS \\
\hline RE ( $\%$ GE) & 1.7 & 7.0 & 9.4 & 0.3 & $\star \star$ & $\star \star$ & * \\
\hline ME (MJ/kg DM) & 9.77 & 10.46 & 10.84 & 0.07 & * & $\star \star \star$ & NS \\
\hline $\mathrm{NE}_{1}(\mathrm{MJ} / \mathrm{kg} \mathrm{DM})$ & 5.62 & 6.74 & 7.02 & 0.14 & * & * & NS \\
\hline UFL/kg DM & 0.79 & 0.95 & 0.99 & 0.02 & * & * & NS \\
\hline
\end{tabular}

${ }^{*} P<0.05 ;{ }^{* *} P<0.01 ;{ }^{* * *} P<0.001$

The data obtained (see table) indicate that the concentrate proportion in the diet positively influences dry matter intake and milk yield $(P<0.001)$ but not milk fat and protein. Energetically, for most of the parameters considered there were significant differences between diet 70 and the others, but not between diet 50 and diet 30 . Particularly, diet 70 had higher energy losses both as faeces $(P<0.001)$, as urine and methane (NS) and as heat production $(P<0.01)$. As a consequence, $R E$ and the nutritive value (expressed as ME, $\mathrm{NE}_{1}$ or $\left.\mathrm{UFL}\right)$ was minimum for diet $70(\mathrm{P}<0.05)$. On the other hand, diets 50 and 30 had similar nutritive values.

The data obtained suggest that, at the conditions of the experiment (stage of lactation and level of production), there was a substantial improvement in increasing the concentrate proportion from 0.3 to 0.5 in the diet. Concentrate proportions higher than 0.5 showed better milk yield performance, but no significant advantage in the efficiency of energy utilization. 